\title{
Brazilian soybean Glycine max (L.) Merr. cultivars adapted to low latitude regions: seed composition and content of bioactive proteins
}

\author{
ILKA M. VASCONCELOS ${ }^{2,5}$, CLAUDIO C. CAMPELLO ${ }^{1}$, JOSÉ TADEU A. OLIVEIRA ${ }^{2}$, \\ ANA F. URANO CARVALHO ${ }^{3}$, DANIELE O. BEZERRA DE SOUSA ${ }^{2}$ and FERNANDA M.M. MAIA ${ }^{4}$
}

(received: November 03, 2005; accepted: October 19, 2006)

\begin{abstract}
Brazilian soybean Glycine max (L.) Merr. cultivars adapted to low latitude regions: seed composition and content of bioactive proteins). Among the goals of the Brazilian soybean improvement programmes, the breeding strategies for cultivars adapted to low latitudes have been included to extend crop areas and to increase production. Seeds of nine Brazilian soybean cultivars adapted to low latitudes were investigated regarding to their composition, and amino acid and antinutritional/ toxic protein contents. Protein ( $394.5 \pm 13.1$ to $445.3 \pm 8.0 \mathrm{~g} \mathrm{~kg}^{-1}$ dry matter) and oil (200.6 \pm 1.2 to $232.3 \pm 4.7 \mathrm{~g} \mathrm{~kg}^{-1}$ dry matter) contents showed low correlation to each other $(r=-0.06)$. The total carbohydrate $\left(141.7 \pm 6.1\right.$ to $211.1 \pm 15.0 \mathrm{~g} \mathrm{~kg}^{-1} \mathrm{dry}^{-1}$ matter $)$ and ash contents ( $48.2 \pm 4.2$ to $52.2 \pm 0.5 \mathrm{~g} \mathrm{~kg}^{-1}$ dry matter) were similar to data available for other soybean cultivars. All soybean cultivars presented low levels of tryptophan and sulphur amino acids. The lectin (1,152 to $147,456 \mathrm{HU} \mathrm{kg}^{-1}$ flour), trypsin inhibitor (34.45 \pm 2.28 to $77.62 \pm 2.63 \mathrm{~g}$ trypsin inhibited kg-1 flour), toxin $\left(6,210 \pm 134\right.$ to $34,650 \pm 110 \mathrm{LD}_{50} \mathrm{~kg}^{-1}$ flour) and urease $\left(0.74 \pm 0.02\right.$ to $1.22 \pm 0.10 \mathrm{~g} \mathrm{~kg}^{-1}$ flour) presented variations in their contents amongst the cultivars. Compared to other soybean cultivars, urease was higher, the acute toxicity lower and the lectin and trypsin inhibitor contents similar to data available. In general, soybean cultivars showed similar biochemical composition to those developed in different geographic regions. The relevance of these findings to the agronomic features and to choice of soybean cultivars to be used as food or feed is discussed.
\end{abstract}

Key words - amino acid content, antinutritional factors, seed composition, soybean, toxicity

RESUMO-(Cultivares brasileiras de soja Glycine max (L.) Merr. adaptadas ao cultivo em baixas latitudes: composição da semente e conteúdo de proteínas bioativas). Dentre os objetivos dos programas de melhoramento da soja no Brasil, está o desenvolvimento de estratégias para obtenção de cultivares adaptadas às regiões de baixas latitudes, visando a ampliação da área cultivada e o aumento da produção. Sementes de nove cultivares brasileiras de soja adaptadas a estas condições foram investigadas em relação à sua composição proximal e conteúdos de aminoácidos e proteínas tóxicas e/ou antinutricionais. Os conteúdos de proteína (394,5 $\pm 13,1$ a 445,3 $\pm 8,0 \mathrm{~g} \mathrm{~kg}^{-1}$ matéria seca) e óleo $\left(200,6 \pm 1,2\right.$ a 232,3 $\pm 4,7 \mathrm{~g} \mathrm{~kg}^{-1}$ matéria seca) mostraram baixa correlação $(\mathrm{r}=-0,06)$. Os conteúdos de carboidratos totais ( $141,7 \pm 6,1$ a $211,1 \pm 15,0 \mathrm{~g} \mathrm{~kg}^{-1}$ matéria seca) e cinzas (48,2 $\pm 4,2$ a 52,2 $\pm 0,5 \mathrm{~g} \mathrm{~kg}^{-1}$ matéria seca) foram similares aos dados disponíveis para outras cultivares de soja. As cultivares estudadas apresentaram baixos teores de triptofano e aminoácidos sulfurados e ampla variação nos conteúdos de lectina (1.152 a $147.456 \mathrm{HU} \mathrm{kg}^{-1}$ farinha), inibidores de tripsina (34,45 $\pm 2,28$ a 77,62 $\pm 2,63 \mathrm{~g}$ tripsina inibida kg $\left.\mathrm{karinh}^{-1}\right)$, toxina $\left(6.210 \pm 134 \mathrm{a} 34.650 \pm 110 \mathrm{DL}_{50} \mathrm{~kg}^{-1}\right.$ farinha) e urease $(0,74$ $\pm 0,02$ a 1,22 $\pm 0,10 \mathrm{~g} \mathrm{~kg}^{-1}$ farinha). Comparados com outras cultivares de soja, os conteúdos de urease verificados foram superiores, a toxicidade aguda observada foi inferior e os conteúdos de lectina e inibidores de tripsina foram semelhantes aos resultados disponíveis na literatura. De um modo geral, as cultivares estudadas mostraram composição bioquímica similar àquela verificada para genótipos desenvolvidos em outras regiões geográficas. A relevância desses achados para as propriedades agronômicas e a seleção de cultivares de soja para a alimentação de seres humanos e animais são discutidas.

Palavras-chave - composição química da semente, conteúdo de aminoácidos, fatores antinutricionais, soja, toxicidade

\section{Introduction}

Soybean (Glycine max (L.) Merr.) is currently the most important source of edible oil and high-quality plant

\footnotetext{
1. Universidade Estadual do Ceará, Faculdade de Veterinária, 60740-000 Fortaleza, CE, Brazil.

2. Universidade Federal do Ceará, Departamento de Bioquímica e Biologia Molecular, Campus do Pici, Caixa Postal 6020, 60451-970 Fortaleza, CE, Brazil.

3. Universidade Federal do Ceará, Departamento de Biologia, 60451-970 Fortaleza, CE, Brazil.

4. Universidade Estadual do Ceará, Centro de Ciências da Saúde, 60740-000 Fortaleza, CE, Brazil.

5. Corresponding author: imvasco@ufc.br
}

protein for feeding both human and animals worldwide (Zeller 1999, Friedman \& Brandon 2001). Originated from mid latitude regions, this species is expanding in tropical areas as a result of the development of new genotypes tolerant to the environmental adversities of these localities (Vasconcelos et al. 1997, Campelo et al. 1999). One of the largest soybean producers of the world is Brazil, a tropical country that comprises an extensive ecological region with wide variation in the environmental conditions. In this country, soybean was firstly grown in the South (in mid latitude areas) and more recently next to Equator line, in the Northeastern region, owing to the development of genotypes with high 
productivity, well adapted to photoperiod effect and resistant to local pathogens and pests (Almeida et al. 1999). Presently, in these places, soybean cultivation has great economic and social importance.

It has been reported that the environmental conditions such as latitude, altitude, temperature and precipitation can affect the seed composition as, for example, the protein and oil contents (Zeller 1999, Van Barneveld 1999). Indeed, Qin et al. (1998) showed that the contents of antinutritional factors were different between raw soybeans produced in two distinct geographical regions. Vollmann et al. (2000) described genetic variations and significant differences in the protein content of soybeans cultivated in distinct climates. Based on these facts, it is reasonable to question whether the soybean cultivars adapted to grow in the Brazilian low latitude regions present differences in their seed composition and nutritional profile when compared to cultivars grown in distinct regions around the world. Furthermore, information on the chemical composition and antinutritional and/or toxic protein contents of soybean cultivars exposed to typical tropical environment is scarce.

Thus, the present work was undertaken to evaluate the proximate composition, amino acid content and the presence of trypsin inhibitor, lectin, urease and intraperitoneal acute toxicity of seeds of nine newly developed soybean cultivars adapted to low latitudes in Brazil.

\section{Material and methods}

Description of seeds and production fields - Mature seeds of nine soybean (Glycine max (L.) Merr.) cultivars ('M. Soy 108', 'Pati', 'Mirador', '9001', 'Cristalina-RCH', 'Seridó-RCH', 'FT 106', 'FT 107' and 'Sambaíba') adapted to low latitude regions were provided by FAPCEN (Fundação de Apoio à Pesquisa do Corredor de Exportação Norte - Maranhão Brazil). The seeds were collected in soy culture areas in the Cerrado ecosystem from Balsas Municipality, located on the south of Maranhão State, Brazil, approximately to $7^{\circ} 31$ ' $57^{\prime \prime}$ S and $46^{\circ} 02^{\prime} 08^{\prime \prime} \mathrm{W}$. Crop fields were characterized by geology consisting of a sedimentary structure composed by sandstones, siltand and claylayers forming a plan geomorphology with altitude from 300 to $500 \mathrm{~m}$. The soils areas are represented for Quartzarenic Neosols (extremely low native fertility, deep, very well drained composed of sand sized quartz grains), Argisols (moderately deep, drained with clay horizon) and Litholic Neosols (very shallow soils, with the parent material less than $0.5 \mathrm{~m}$ from the surface), which required extensive modification for viable crop production. The area is characterized by tropical climate, hot and humid, with rainy season lasts from September and August. The annual average rainfall is around $1,400 \mathrm{~mm}$, whilst air temperature varies from 25 to $36^{\circ} \mathrm{C}$, with a mean of $30^{\circ} \mathrm{C}$. The relative humidity of the air is high, with $40 \%$ on the dry season. The Cerrado vegetation is predominant and consists of sparse trees of low to medium height with tortuous stems.

Proximate analysis - Seed moisture, crude fibre, ash and oil contents were determined by AOAC method (1990). Total nitrogen (Baethgen \& Alley 1989) was used for determination of seed crude protein contents $(\mathrm{N} \times 5.5)$. Total carbohydrate contents were calculated by difference from all the other constituents.

Amino acid composition - Defatted seed flours were hydrolysed with $6 \mathrm{M} \mathrm{HCl}$ containing $10 \mathrm{~g} \mathrm{~L}^{-1}$ phenol at $110^{\circ} \mathrm{C}$ for 22 hours in sealed glass tubes under $\mathrm{N}_{2}$ atmosphere. After removal of $\mathrm{HCl} /$ phenol by evaporation, the amino acid compositions were established after chromatography on a Biochrom 20 System (Pharmacia). Tryptophan content was measured colorimetrically (Pintér-Szakács \& Molnár-Perl 1990).

Aqueous soybean crude extracts - The seeds were ground in a coffee grinder to a fine powder. The meals were defatted with petroleum ether $\left(100 \mathrm{~g} \mathrm{~L}^{-1}, \mathrm{w} / \mathrm{v}\right)$ under continuous stirring for 72 hours, air-dried at room temperature and stored at $4{ }^{\circ} \mathrm{C}$. For preparation of the aqueous crude extract, the defatted meal was suspended in the extracting buffer $(0.025 \mathrm{M}$ Tris$\mathrm{HCl}, \mathrm{pH} \mathrm{7.5)}$ in the proportion of $1.0 \mathrm{~g}$ of meal to $5 \mathrm{~mL}$ of buffer. The suspension was maintained under continuous stirring ( $400 \mathrm{rpm}$ ) during 3 hours at $4{ }^{\circ} \mathrm{C}$ and then filtered. The press cake was reextracted during 2 hours under the same conditions. The filtrate was centrifuged at $15,000 \mathrm{~g}$ for 30 minutes at $4{ }^{\circ} \mathrm{C}$ and the clear supernatant dialysed (cut-off MW 12,000) overnight against the extracting buffer. The crude seed extract from each cultivar was the starting material for the detection of haemagglutinating and toxic activities. The crude extract of each seed was further fractionated by saturation to $20 \%-55 \%\left(\mathrm{~F}_{20-55 \%}\right)$ with solid ammonium sulphate. The precipitate was dissolved in and dialyzed exhaustively against $0.025 \mathrm{M}$ Tris-HCl, $\mathrm{pH} 7.5$. Toxic activity of this fraction was also assayed.

Soluble protein determination - The protein content in the seed extracts was determined by the method described by Bradford (1976) using bovine serum albumin (96\%, Sigma Chemical Co, St. Louis, MO, USA), as standard.

Trypsin inhibitor activity - The protease inhibitor assay was carried out by a slight modification of the method originally described by Kakade et al. (1974) and Hamerstrand et al. (1981). Defatted soybean meal (0.02 g) was suspended in $1 \mathrm{~mL}$ of $0.01 \mathrm{M} \mathrm{NaOH}$ in an microcentrifuge tube and the suspension was stirred magnetically for 3 hours. The mixture was then left for 30 minutes without stirring and then $0.5 \mathrm{~mL}$ of the supernatant was mixed with $0.5 \mathrm{~mL}$ of $0.01 \mathrm{M} \mathrm{NaOH}$. This solution was centrifuged 5 minutes at $10,000 \mathrm{~g}$. After centrifugation, $0.1 \mathrm{~mL}$ of the alkaline extract was mixed with $1.6 \mathrm{~mL} 0.05 \mathrm{M}$ Tris-HCl, $\mathrm{pH} 8.2$, containing $0.02 \mathrm{M} \mathrm{CaCl}_{2}$, with 
$0.1 \mathrm{~mL}$ of trypsin solution (from a stock solution of $0.4 \mathrm{mg}$ in $10 \mathrm{~mL} 0.001 \mathrm{M} \mathrm{HCl}$ ) plus $0,1 \mathrm{~mL}$ of $N$ - $\alpha$-benzoyl-L-arginine $p$-nitroanilide solution $\left(10 \mathrm{mg} \mathrm{mL}^{-1}\right.$ in $97 \%$ dimethyl sulfoxide plus $\mathrm{H}_{2} \mathrm{O}, 1: 3 \mathrm{v} / \mathrm{v}$ ). The mixture was incubated for 45 minutes at $37{ }^{\circ} \mathrm{C}$ and then $0.2 \mathrm{~mL} 30 \%$ acetic acid solution was added. The absorbance was measured at $410 \mathrm{~nm}$. Activity was expressed as the amount of trypsin inhibited calculated from a calibration curve using purified soybean trypsin inhibitor. Haemagglutination assay - Haemagglutination activity was assessed by serial twofold dilution of the aqueous extracts (Moreira \& Perrone 1977, Vasconcelos et al. 1991). The extracts were diluted with $0.15 \mathrm{M} \mathrm{NaCl}$ in glass tubes and mixed with rabbit red cells $\left(20 \mathrm{mg} \mathrm{mL}^{-1}\right.$ suspension prepared in $0.15 \mathrm{M}$ $\mathrm{NaCl}$ ) with or without previous proteolytic enzyme treatment. The degree of agglutination was monitored visually after the tubes had been left at $37^{\circ} \mathrm{C}$ for 30 minutes and then left at room temperature for further 30 minutes. The enzyme (trypsin, bromelain, subtilisin or papain) treated cells were obtained by incubating $25 \mathrm{~mL} 20 \mathrm{mg} \mathrm{mL}^{-1}$ red cell suspension with the enzyme $(0.1 \mathrm{mg})$ for 60 minutes at $4^{\circ} \mathrm{C}$, followed by washings, six times, with $0.15 \mathrm{M} \mathrm{NaCl}$. The results were expressed as haemagglutinating titre (HU), which is the reciprocal of the highest dilution giving visible agglutination.

Acute toxicity assay - The acute toxicity of the Brazilian soybean crude extracts and $\mathrm{F}_{(20-55 \%)}$ was measured using 2-3 month-old adult male Swiss mice, reared in the animal house of the Universidade Federal do Ceará according to Vasconcelos et al. (1994). The animals were housed under the optimum temperature condition for mice $\left(22 \pm 2^{\circ} \mathrm{C}\right)$ and light was set at 12 hours light/dark. The mice had unrestricted access to a commercial mouse diet and tap water. The acute toxic activity was defined as the mortality observed in mice within 24 hours after intraperitoneal injections of the crude extracts. One $\mathrm{LD}_{50}$ unit was taken as the amount of protein (in $\mathrm{g}$ protein $\mathrm{kg}^{-1}$ mouse body weight) producing convulsions and death of $50 \%$ animals tested (six doses; six mice per dose). The trial was conducted under official welfare guidelines and protocols covering animal experimentation at the university.

Urease assay - The crude extract was obtained by suspension of the meals in $0.01 \mathrm{M}$ monobasic sodium phosphate buffer, $\mathrm{pH} 7.0$, containing $0.15 \mathrm{M} \mathrm{NaCl}$, using the same protocol previously described. Urease assay was carried out by minor modifications of the procedure described by Kaplan (1969). To $0.1 \mathrm{~mL}$ of $0.5 \mathrm{M}$ urea solution was added $0.7 \mathrm{~mL}$ of $20 \mathrm{mg} \mathrm{mL}^{-1}$ EDTA buffered with $0.2 \mathrm{M}$ potassium phosphate, $\mathrm{pH}$ 6.5, and $0.1 \mathrm{~mL}$ of crude extract (containing $0.2 \mathrm{mg}$ protein $\mathrm{mL}^{-1}$ ). This mixture was incubated for 15 minutes at $37^{\circ} \mathrm{C}$ followed by the addition of $1 \mathrm{~mL}$ of phenol plus sodium nitroprusside solution $(62.0 \mathrm{~g}$ phenol with $0.25 \mathrm{~g}$ of sodium nitroprusside $\mathrm{L}^{-1}$ ) and $1 \mathrm{~mL}$ of sodium hypochlorite plus alkali solution ( $43.0 \mathrm{~mL}$ of $52.5 \mathrm{~g} \mathrm{l}^{-1} \mathrm{NaClO}$ with $20.0 \mathrm{~g}$ of $\left.\mathrm{NaOH} \mathrm{L}{ }^{-1}\right)$. The mixture was incubated for further 5 minutes at $37^{\circ} \mathrm{C}$. After that, $7 \mathrm{~mL}$ of distilled water was added. The tubes were shaken vigorously and the absorbance measured at
$625 \mathrm{~nm}$. The enzyme activity was calculated from a calibration curve using urease (41H7008, 870000 units $\mathrm{g}^{-1}$ Sigma Chemical Co, St. Louis, MO, USA).

Sodium dodecyl sulphate polyacrylamide gel electrophoresis (SDS-PAGE) - SDS-PAGE was performed according to the method of Laemmli (1970). It was carried out in a 3.5-mm vertical slab gel $(18,5 \times 16,5 \mathrm{~cm})$ consisting of stacking gel mix, $5 \%$ total acrylamide, and main running gel mix, 15\% acrylamide, prepared in 1.5 M Tris-HCl, $\mathrm{pH}$ 8.8. Samples were dissolved in Tris- $\mathrm{HCl} 0.125 \mathrm{M}, \mathrm{pH} 6.8$, containing $1 \% \mathrm{SDS}$ and $1 \%$ 2-mercaptoethanol and incubated at $100{ }^{\circ} \mathrm{C}$ for 10 minutes. Electrophoresis was carried out at $40 \mathrm{~mA}$ constant electric current for 6 hours. Protein bands were visualized by staining with $0.05 \%$ Coomassie brilliant blue R-250. Protein markers employed were bovine serum albumin $(66 \mathrm{kDa})$, ovalbumin (45 kDa), glyceraldehyde-3-phosphate dehydrogenase $(36 \mathrm{kDa})$, carbonic anhydrase $(29 \mathrm{kDa})$, trypsinogen $(24 \mathrm{kDa})$, soybean trypsin inhibitor $(20.1 \mathrm{kDa})$ and a-lactalbumin (14.2 kDa).

Statistical analysis - The results were subjected to analysis of variance and the significance between means determined by Tukey's test $(P<0.05)$.

\section{Results and Discussion}

As expected, the nine soybean cultivars studied in this present work were rich in protein, varying from $394.5 \pm 13.1$ to $445.3 \pm 8.0 \mathrm{~g} \mathrm{~kg}^{-1}$ dry matter, and oil, varying from $200.6 \pm 1.2$ to $232.3 \pm 4.7 \mathrm{~g} \mathrm{~kg}^{-1}$ dry matter (table 1). Although the protein contents of the cultivars are comparable to those of available data on other soybean cultivars (Vasconcelos et al. 1997, Wilcox 1998, Vollman et al. 2000, Ridley et al. 2004), the results evidenced some variability among the nine cultivars. For example, cv. Pati, which presented the highest protein content, had around $11 \%$ more protein than cv. FT 107 (table 1). Regarding to the oil contents, the values found for the nine Brazilian soybean cultivars are close to those reported for other soybean cultivars (Vasconcelos et al. 1997, Fernández-Quintela et al. 1998). The sum of protein and oil contents represents around $636.3 \mathrm{~g} \mathrm{~kg}^{-1}$ dry matter, i.e., more than $50 \%$ of the whole seed (table 1). This value is higher than that reported by Vieira et al. (1999). Although the protein contents were nearly twofold higher than the oil, their amounts in the seeds had no correlation $(r=-0.06)$. Hence these current data and those reported by Armour et al. (1998) did not support the negative association between the seed protein and the oil contents suggested before (Wilcox 1998, Vieira et al. 1999). This information may be important in soybean improvement programmes. Although the upper limit of increasing simultaneously 
Table 1. Proximate composition ${ }^{\mathrm{a}}\left(\mathrm{g} \mathrm{kg}^{-1}\right.$ dry matter $\left.\pm \mathrm{SD}\right)$ of Brazilian soybean cultivars

\begin{tabular}{|c|c|c|c|c|c|}
\hline Cultivar & Moisture & Protein ${ }^{b}$ & Oil & Ash & Carbohydrate $^{\mathrm{c}}$ \\
\hline G. max 'M. Soy' & $81.8 \pm 1.1 \mathrm{a}$ & $406.4 \pm 27.4 b$ & $213.9 \pm 1.9 \mathrm{c}$ & $50.9 \pm 0.3$ & $199.3 \pm 41.5 \mathrm{ab}$ \\
\hline G. max 'Pati' & $72.0 \pm 0.3 \mathrm{~cd}$ & $445.3 \pm 8.0 \mathrm{a}$ & $224.4 \pm 1.1 b$ & $50.5 \pm 0.3$ & $141.7 \pm 6.1 b$ \\
\hline G. max 'Mirador' & $78.3 \pm 1.0 b$ & $400.9 \pm 27.6 b$ & $207.0 \pm 1.2 \mathrm{~d}$ & $49.1 \pm 0.5$ & $203.6 \pm 16.7 \mathrm{ab}$ \\
\hline G. $\max$ '9001' & $80.1 \pm 1.7 \mathrm{ab}$ & $425.2 \pm 11.5 \mathrm{ab}$ & $200.6 \pm 1.2 \mathrm{~d}$ & $52.2 \pm 0.5$ & $176.3 \pm 12.5 \mathrm{ab}$ \\
\hline G. $\max$ 'Cristalina-RCH' & $74.1 \pm 1.5 \mathrm{c}$ & $420.1 \pm 6.7 \mathrm{ab}$ & $223.3 \pm 2.3 b$ & $48.2 \pm 4.2$ & $176.6 \pm 15.6 \mathrm{ab}$ \\
\hline G. max 'Seridó-RCH' & $71.0 \pm 1.3 \mathrm{~cd}$ & $444.1 \pm 6.6 \mathrm{a}$ & $213.6 \pm 3.1 \mathrm{c}$ & $50.4 \pm 1.1$ & $158.1 \pm 9.2 \mathrm{ab}$ \\
\hline G. max 'FT 106' & $78.1 \pm 0.5 b$ & $405.4 \pm 27.0 \mathrm{~b}$ & $223.0 \pm 0.6 b$ & $49.3 \pm 0.9$ & $186.8 \pm 42.6 \mathrm{ab}$ \\
\hline G. $\max { }^{\prime} \mathrm{FT} 107$ ' & $71.8 \pm 2.0 \mathrm{~cd}$ & $394.5 \pm 13.1 b$ & $227.6 \pm 1.6 \mathrm{ab}$ & $48.3 \pm 0.3$ & $211.1 \pm 15.0 \mathrm{a}$ \\
\hline G. max 'Sambaíba' & $67.7 \pm 2.4 \mathrm{~d}$ & $418.9 \pm 4.1 \mathrm{ab}$ & $232.3 \pm 4.7 \mathrm{a}$ & $48.3 \pm 0.4$ & $177.0 \pm 7.4 \mathrm{ab}$ \\
\hline
\end{tabular}

${ }^{\mathrm{a}}$ Means of triplicate analyses. Values followed by different letters are statistically different $(P<0.05)$; ${ }^{\mathrm{b}} \mathrm{N} \times 5.5$; $\mathrm{c}$ Calculated by difference.

protein and lipid contents is not yet predicted, these results show that the genetic improvement in the content of one of these two components is not necessarily accompanied by a reduction in the amount of the other seed compound and vice-versa.

The ash contents varied from 48.2 44.2 to $52.2 \pm 0.5 \mathrm{~g} \mathrm{~kg}^{-1}$ dry matter (table 1 ) and no significant variation was observed among the cultivars. Furthermore, they are comparable to data reported by Férnandez-Quintela et al. (1997), slightly higher than those observed by Vasconcelos et al. (1997), but a little lower when compared to results obtained by Vieira et al. (1999). The carbohydrate contents varied from $141,7 \pm 6,1$ a $211,1 \pm 15,0 \mathrm{~g} \mathrm{~kg}^{-1}$ dry matter (table 1 ). According to Bau et al. (1997), mature soybeans contain only traces of starch, but are rich sources of dietary fibre particularly in hemicellulose and cellulose, and are poor in lignin, features that have been shown to produce beneficial effects on glucose and lipid metabolism.

The amino acid profiles of the Brazilian soybean cultivars and that of the hen egg, together with the minimal requirements of essential amino acids established for 2-5 and 10-12-year-old children (FAO/ WHO/UNU 1985) are presented in table 2. Overall, the seed meal amino acid compositions were very similar. Regardless the cultivar analysed there was prevalence of the glutamine/glutamic acid (209.0 to $228.3 \mathrm{~g} \mathrm{~kg}^{-1}$ protein) and asparagine/aspartic acid (112.2 to $149.6 \mathrm{~g} \mathrm{~kg}^{-1}$ protein). Both glutamine and asparagine, which are derived from glutamic acid and aspartic acid, respectively, constitute important reservoirs of amino groups for the body. The total contents of essential amino acids in the studied cultivars ranged from 377.8 to $415.0 \mathrm{~g} \mathrm{~kg}^{-1}$ protein, which are very close to those reported by Vasconcelos et al. (1997), Vieira et al.
(1999) and Ridley et al. (2004). Analysis of the chemical scores (CS) of the essential amino acids revealed that most of them have contents below to those of the corresponding amino acids in the hen egg protein (FAO/WHO/UNU 1985). As reported for other legumes, the soybean cultivars presented methionine + cysteine and tryptophan as the first and second limiting amino acids, respectively. When these figures were compared to FAO/WHO/UNU (1985) scoring patterns of amino acid requirements for children (2-5 and 10-12 years old), the cultivars showed to be also deficient in methionine + cysteine and tryptophan. Tryptophan was the first limiting amino acid for six out of the nine studied soybean cultivars (Glycine max (L.) Merr. 'M. Soy', 'Pati', 'Cristalina-RCH', 'SeridóRCH', 'FT 106' and 'FT 107') whereas the sulphurcontaining amino acids were the first limiting ones for the remaining cultivars (Glycine max 'Mirador', '9001' and 'Sambaíba'). All other essential amino acids met the children's needs, although the contents of most of them were lower than those for hen egg. Deficiency of the sulphur amino acids is common in the great majority of leguminous seeds (Friedman et al. 1991, Duranti \& Gius 1997). It is well known that cystine, cysteine and methionine are destroyed to varying degrees during hydrochloric acid hydrolysis (Gehrke et al. 1985). In this work, it was used $6 \mathrm{M} \mathrm{HCl}+$ $10 \mathrm{~g} \mathrm{~L}^{-1}$ phenol to prevent degradation of some amino acids (Gehrke et al. 1985). In this condition, loss of methionine and cysteine may have occurred, but to a lesser extension. The insignificant values of methionine + cysteine need to be considered when the proteins are used for nutritional purpose. Nevertheless, these low contents must not be seen only as a nutritional limitation. Messina (1999) showed that low contents 
Table 2. Amino acid composition ( $\mathrm{g} \mathrm{kg}^{-1}$ protein) of Brazilian soybean cultivars compared with hen egg and FAO/WHO/UNU scoring patterns of amino acid requirements for children.

\begin{tabular}{|c|c|c|c|c|c|c|c|c|c|c|c|c|}
\hline \multirow[t]{2}{*}{ Amino aci } & \multicolumn{9}{|c|}{ Cultivars } & \multirow{2}{*}{$\begin{array}{l}\text { Hen } \\
\text { Egg }\end{array}$} & \multicolumn{2}{|c|}{ Children $^{\mathrm{a}}$} \\
\hline & 'M. soy' & 'Pati' & 'Mirador' & '9001' & $\begin{array}{c}\text { 'Cristalina- } \\
\text { RCH' }\end{array}$ & $\begin{array}{l}\text { 'Seridó- } \\
\text { RCH' }\end{array}$ & 'FT 106' & 'FT 107' & 'Sambaíba' & & $\begin{array}{c}2-5 \\
\text { y-old }\end{array}$ & $\begin{array}{l}10-12 \\
y-o l d\end{array}$ \\
\hline Thr & 34.5 & 36.1 & 35.2 & 34.9 & 35.5 & 34.3 & 36.1 & 35.1 & 34.6 & 47 & 34 & 28 \\
\hline Val & 43.2 & 45.8 & 40.6 & 40.9 & 47.2 & 44.3 & 44.7 & 43.6 & 41.4 & 66 & 35 & 25 \\
\hline Ile & 47.0 & 44.5 & 44.4 & 44.4 & 49.9 & 48.7 & 44.0 & 48.0 & 44.6 & 54 & 28 & 28 \\
\hline Leu & 79.8 & 78.2 & 77.2 & 77.0 & 85.6 & 82.4 & 72.5 & 83.1 & 77.7 & 86 & 66 & 44 \\
\hline Lys & 58.9 & 59.1 & 58.4 & 60.1 & 61.5 & 58.5 & 61.7 & 60.6 & 58.7 & 70 & 58 & 44 \\
\hline Phe + Tyr & 89.5 & 97.3 & 87.2 & 87.2 & 96.4 & 92.8 & 101.7 & 92.1 & 90.1 & 93 & 63 & 22 \\
\hline Met + Cys & 11.9 & 8.3 & 6.6 & 6.1 & 9.0 & 7.8 & 8.1 & 6.8 & 7.3 & 57 & 25 & 22 \\
\hline Trp & 3.1 & 3.3 & 3.3 & 2.8 & 2.7 & 2.9 & 2.5 & 2.3 & 3.6 & 17 & 11 & 09 \\
\hline His & 28.3 & 25.8 & 24.9 & 27.9 & 27.2 & 24.4 & 28.2 & 25.8 & 23.7 & 22 & 19 & 19 \\
\hline Asx & 119.3 & 115.2 & 149.6 & 149.4 & 115.3 & 113.1 & 112.2 & 116.6 & 148.5 & & & \\
\hline Glx & 222.8 & 225.2 & 224.6 & 214.3 & 224.4 & 226.1 & 209.0 & 228.3 & 217.9 & & & \\
\hline Ser & 40.4 & 43.2 & 41.8 & 40.6 & 42.8 & 42.5 & 42.5 & 42.5 & 40.1 & & & \\
\hline Gly & 36.7 & 38.0 & 34.8 & 36.5 & 37.8 & 36.5 & 38.3 & 36.2 & 35.0 & & & \\
\hline Ala & 47.0 & 49.2 & 45.2 & 43.5 & 48.2 & 46.7 & 49.6 & 46.3 & 43.7 & & & \\
\hline Arg & 91.3 & 82.3 & 81.1 & 90.8 & 84.2 & 91.2 & 94.4 & 85.1 & 87.3 & & & \\
\hline Pro & 45.9 & 48.4 & 44.8 & 43.9 & 32.4 & 48.1 & 54.1 & 47.6 & 45.6 & & & \\
\hline
\end{tabular}

${ }^{\text {a }}$ Patterns of amino acid requirements for different age groups.

of sulphur amino acids might actually provide an advantage, since hydrogen ions produced from the sulphur amino acid metabolism can cause demineralisation of bone and excretion of calcium in urine.

The presence of lectin is depicted in table 3 . Untreated or enzyme-treated rabbit erythrocytes were agglutinated in the presence of aqueous crude extract from all studied soybean cultivars. Enzyme-treated cells were more sensitive to agglutination than the untreated cells probably owing to a greater exposure of the carbohydrate moieties present in the cell membrane for which the lectin has higher affinity. Both total $(1,152$ to $147,456 \mathrm{HU} \mathrm{kg}^{-1}$ flour) and specific $(2,920$ to $373,779 \mathrm{HU} \mathrm{g}^{-1}$ protein) haemagglutinating activities showed a wide variation amongst the cultivars. The crude extracts from Cristalina-RCH and FT 107 cultivars presented the more noticeable total haemagglutinating activity against enzyme-treated rabbit erythrocytes. It has been long known that some lectins are considered important antinutritional factors since they are resistant to digestion by proteolytic enzymes and so, when present in diets, may cause alterations in gut and systemic metabolism by interacting with glycoconjugates on the gut cell membrane. These interactions may induce disruption of the brush border, atrophy of microvilli, hyperplasia of crypt cells, loss of viability of epithelial cells and also macroscopical alterations of key organs (Pusztai et al. 1995, Lajolo \& Genovese 2002).

The trypsin inhibitor activity is shown in table 4 . All the nine studied soybean crude extracts were able to inhibit trypsin. The amounts of trypsin inhibited in the studied cultivars varied from $34.45 \pm 2.28$ to $77.62 \pm 2.63 \mathrm{~g} \mathrm{~kg}^{-1}$ flour. The G. max 'M. Soy' and G. max 'Paty' presented the highest contents of trypsin inhibitor, whereas G. $\max$ 'Mirador' and G. $\max$ 'Sambaíba' showed the lowest ones. Variation in the protease inhibitor contents had already been observed in several soybean cultivars (Vasconcelos et al. 1997, Bau et al. 1997). Nevertheless, the contents of trypsin inhibitor found for the nine cultivars of the present study showed to be similar or slightly higher than those reported for other soybean cultivars (Vasconcelos et al. 1997, Sousa 2001, Brasil 2002, Olguin et al. 2003). Trypsin inhibitors interfere with the physiological functions of the trypsin, which consist of both proenzyme activation and hydrolysis of dietary proteins in the gut. Because of this double action, trypsin inhibitors are the main components claimed to be responsible for the poor digestibility of dietary proteins (Evenepoel et al. 2000, Bajpai et al. 2005). On the other hand, it is known that trypsin inhibitors are sulphur amino acid rich proteins and accordingly contribute substantially to the methionine content of soybeans (Clarke \& Wiseman 
Table 3. Lectin activity of crude extracts from Brazilian soybean cultivars against untreated and enzyme treated rabbit erythrocytes.

\begin{tabular}{|c|c|c|c|c|c|c|c|c|c|}
\hline \multirow[b]{2}{*}{ Lectin activity ${ }^{\mathrm{a}}$} & \multicolumn{9}{|c|}{ Cultivars } \\
\hline & 'M. soy' & 'Pati' & 'Mirador' & '9001' & $\begin{array}{c}\text { 'Cristalina- } \\
\text { RCH' }\end{array}$ & $\begin{array}{l}\text { 'Seridó- } \\
\text { RCH' }\end{array}$ & 'FT 106' & 'FT 107' & 'Sambaíba' \\
\hline \multicolumn{10}{|c|}{ Total (HU g-1 flour) } \\
\hline Untreated & 18432 & 9216 & 2304 & 4608 & 18432 & 4608 & 2304 & 1152 & 4608 \\
\hline Trypsin & 73728 & 36864 & 9216 & 36864 & 147456 & 36864 & 36864 & 147456 & 36864 \\
\hline Papain & 36864 & 36864 & 9216 & 36864 & 73728 & 36864 & 36864 & 18432 & 36864 \\
\hline Subtilisin & 36864 & 36864 & 4608 & 18432 & 147456 & 18432 & 36864 & 18432 & 18432 \\
\hline Bromelain & 36864 & 36864 & 9216 & 36864 & 147456 & 36864 & 36864 & 36864 & 36864 \\
\hline \multicolumn{10}{|c|}{ Specific $\left(\mathrm{HU} \mathrm{g}^{-1} \text { protein }\right)^{\mathrm{b}}$} \\
\hline Untreated & 45357 & 20697 & 5747 & 10837 & 43874 & 10375 & 5683 & 2920 & 11001 \\
\hline Trypsin & 181426 & 82788 & 22987 & 86694 & 350994 & 83001 & 90928 & 373799 & 88006 \\
\hline Papain & 90713 & 82788 & 22987 & 86694 & 175497 & 83001 & 90928 & 46722 & 88006 \\
\hline Subtilisin & 90713 & 82788 & 11493 & 43347 & 350994 & 41500 & 90928 & 46722 & 44003 \\
\hline Bromelain & 90713 & 82788 & 22987 & 86694 & 350994 & 83001 & 90928 & 93445 & 88006 \\
\hline
\end{tabular}

${ }^{a}$ Lectin activity is expressed as haemagglutinating titre (HU), which is the reciprocal of the highest dilution giving visible agglutination. ${ }^{\mathrm{b}}$ Specific haemagglutinating activity was taken in relation to the seed crude protein content (table 1).

2000). As the seeds are consumed after heat processing, which causes, at least in part, denaturation and inactivation of these proteins, trypsin inhibitors may even play a positive nutritional role (Duranti \& Gius 1997).

The crude extracts of the nine Brazilian soybean cultivars exhibited urease activity (table 4 ). The values varied from $0.74 \pm 0.02$ (FT 106) to $1.22 \pm 0.10 \mathrm{~g} \mathrm{~kg}^{-1}$ flour (G. max 'Seridó-RCH'), corresponding to 643,000 and 1, 061,400 units kg-1 flour, respectively. These data show that these nine cultivars could be regarded as highurease genotypes when compared to some other Brazilian soybean cultivars (G. max 'Rio Balsas', G. max 'Tropical', G. max 'BR-10' and G. max 'Bays') which showed values varying from 0.123 to $0.252 \mathrm{~g} \mathrm{~kg}^{-1}$ flour (Vasconcelos et al. 1997). Apparently this variation in the urease content is a common feature within the soybean cultivars and might reflect both genetic and environmental variability (Vasconcelos et al. 1997). Nevertheless, it has been suggested that urease may act as a plant chemical defence against predators rather than have a urea assimilatory role (Polacco \& Holland 1993, Follmer et al. 2002).

Surprisingly none of the crude extracts from the nine soybean cultivars were toxic to mice by intraperitoneal route, even when administered at the highest dose ( $0.3 \mathrm{~mL} 10 \mathrm{~g}^{-1}$ mouse body weight). These results differ from those reported by Vasconcelos et al (1997) who verified toxicity to mice in the crude aqueous extracts of four out of five other soybean cultivars when injected intraperitoneally. As the absence of toxicity was not expected to occur in all the nine cultivars, their crude extracts were fractionated by precipitation with ammonium sulphate at $20 \%-55 \%$ saturation as it was successful done in a similar study conducted with other soybean cultivar (Vasconcelos et al. 1994). Indeed, all the $\mathrm{F}_{20-55 \%}$ obtained from the nine cultivars were able to kill mice within 12 hours when injected by intraperitoneal route, producing acute symptoms, such as dyspnoea, tonic-clonic convulsions and death. The $\mathrm{LD}_{50}$ values varied amongst the $\mathrm{F}_{20-55 \%}$ from 136 to $509 \mathrm{mg}$ protein $\mathrm{kg}^{-1}$ mouse body weight (data not shown), which correspond to $6,210 \pm 134$ to $34,650 \pm 110 \mathrm{LD}_{50} \mathrm{~kg}^{-1}$ flour, respectively (table 4). These figures are close to the values reported for other soybean cultivars (Vasconcelos et al. 1994, Vasconcelos et al. 1997, Sousa 2001, Brasil 2002). The general toxic effects observed were similar

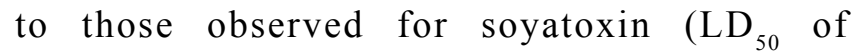
$7.4 \pm 0.3 \mathrm{mg} \mathrm{kg}^{-1}$ mouse body weight, according to Vasconcelos et al. 1994) and soybean toxin $\left(\mathrm{LD}_{50}\right.$ $5.6 \pm 0.1 \mathrm{mg} \mathrm{kg}^{-1}$ mouse body weight) (our unpublished results). As the $\mathrm{F}_{20-55 \%}$ did not represent the pure toxic component free of other seed constituents as were soyatoxin (Vasconcelos et al. 1994) and soybean toxin, their $\mathrm{LD}_{50}$ were very much higher than those of the former soybean proteins. However, it seems important to monitor the levels of toxic proteins in soybean cultivars as nutritional studies showed that they contribute with biological alterations in mice, in addition to soyabean agglutinin (SBA) and trypsin inhibitors (Vasconcelos et al. 2001). Moreover, it is relevant to gather more 
Table 4. Trypsin inhibitor, urease and toxic activities ${ }^{\mathrm{a}}$ of Brazilian soybean cultivars.

\begin{tabular}{|c|c|c|c|}
\hline Cultivars & $\begin{array}{l}\text { Trypsin inhibited } \\
\quad\left(\mathrm{g} \mathrm{kg}^{-1} \text { flour }\right)\end{array}$ & $\begin{array}{c}\text { Urease }^{\mathrm{b}} \\
\left(\mathrm{g} \mathrm{kg}^{-1} \text { flour}\right)\end{array}$ & $\begin{array}{c}\text { Toxin }^{\mathrm{c}} \\
\left(\mathrm{LD}_{50} \mathrm{~kg}^{-1} \text { flour }\right)\end{array}$ \\
\hline G. $\max$ 'M. Soy' & $77.62 \pm 2.63 \mathrm{a}$ & $1.14 \pm 0.04 \mathrm{ab}$ & $12120 \pm 630 \mathrm{bcd}$ \\
\hline G. $\max$ 'Pati' & $62.04 \pm 4.61 b$ & $0.87 \pm 0.07 \mathrm{~d}$ & $18890 \pm 125 b$ \\
\hline G. max 'Mirador' & $34.45 \pm 2.28 \mathrm{e}$ & $0.86 \pm 0.04 d$ & $16490 \pm 173 b c$ \\
\hline G. $\max { }^{`} 9001$ ' & $50.77 \pm 1.99 \mathrm{c}$ & $1.04 \pm 0.05 b c$ & $34650 \pm 110 \mathrm{a}$ \\
\hline G. max 'Cristalina-RCH' & $42.03 \pm 4.43 d$ & $0.97 \pm 0.07 \mathrm{~cd}$ & $11620 \pm 570 \mathrm{~cd}$ \\
\hline G. max ‘Seridó-RCH’ & $49.54 \pm 1.80 \mathrm{c}$ & $1.22 \pm 0.10 \mathrm{a}$ & $15140 \pm 560 \mathrm{bc}$ \\
\hline G. $\max { }^{`} \mathrm{FT} 106$ ’ & $54.08 \pm 2.91 \mathrm{c}$ & $0.74 \pm 0.02 \mathrm{e}$ & $11240 \pm 378 \mathrm{~cd}$ \\
\hline G. $\max { }^{\prime} \mathrm{FT} 107$ ' & $55.38 \pm 4.40 \mathrm{c}$ & $1.16 \pm 0.02 \mathrm{a}$ & $6210 \pm 134 d$ \\
\hline G. max 'Sambaíba' & $38.85 \pm 2.13 \mathrm{de}$ & $1.14 \pm 0.04 \mathrm{ab}$ & $8790 \pm 660 \mathrm{~cd}$ \\
\hline
\end{tabular}

${ }^{\mathrm{a}}$ Each value is an average of six determinations. Values followed by different letters are statistically different $(P<0.05)$. ${ }^{\mathrm{b}} \mathrm{Calculated}$ from Sigma information that $1 \mathrm{~g}$ of pure enzyme contains 870000 units. ${ }^{c} \mathrm{LD}_{50}, 50 \%$ lethal dose. One $\mathrm{LD}_{50}$ represents the amount of protein in g. $\mathrm{kg}^{-1}$ of mouse body weight producing convulsion and death of $50 \%$ of tested animals when injected by intraperitoneal route.

information related to their physiological role since preliminary studies have revealed that these toxins display inhibitory activity against phytopathogenic fungi (our unpublished results).

SDS-PAGE did not reveal differences in the distribution of protein bands amongst the nine soybean cultivars. Exceptions are the protein bands with molecular mass around 27 to $28 \mathrm{kDa}$ (figure 1). Four (G. max 'Mirador', G. max 'FT 106', G. max 'FT 107' and $G$. $\max$ ' 9001 ') of the nine soybean cultivars analyzed showed the presence of a protein band of $M_{\mathrm{r}} 27 \mathrm{kDa}$. On the other hand, in other cultivars ( $G$. max 'M. Soy', G. max 'Pati', G. max 'Seridó-RCH', G. max 'Cristalina-RCH' and G. max 'Sambaíba') this protein band could not be detected, predominating another one of $M_{\mathrm{r}} 28 \mathrm{kDa}$. In addition to the protein bands of $M_{\mathrm{r}} 27$ and $28 \mathrm{kDa}$, the cultivars showed several protein bands with $M_{\mathrm{r}}$ characteristics of $\beta$-conglycinin (three major subunits, namely, $\alpha^{\prime}-72 \mathrm{kDa}, \alpha-68 \mathrm{kDa}$ and $\beta-52$ $\mathrm{kDa}$ ) and glycinin (acid and basic subunits of $\sim 35 \mathrm{kDa}$ and $20 \mathrm{kDa}$, respectively) (Thanh \& Shibasaki 1977, Nielsen 1985).

In conclusion, the data obtained in the present study for the nine Brazilian soybean cultivars confirmed that variations exist among several biochemical parameters depending on the cultivar considered. Thus it is relevant to gather more information on the proximate composition, amino acid content and the presence and levels of antinutritional and/or toxic proteins of the various genetically improved cultivars released for consumption. These results can allow future correlations of data to possibly predict which cultivars possess better nutritional quality and the reasons that explain these differences: whether of genetic origin or derived from plant nutrition status or features of the production area. Furthermore, this information is very relevant to support studies or possible correlations between the levels of antinutritional/ toxic factors and the quality of the soybean derived food/

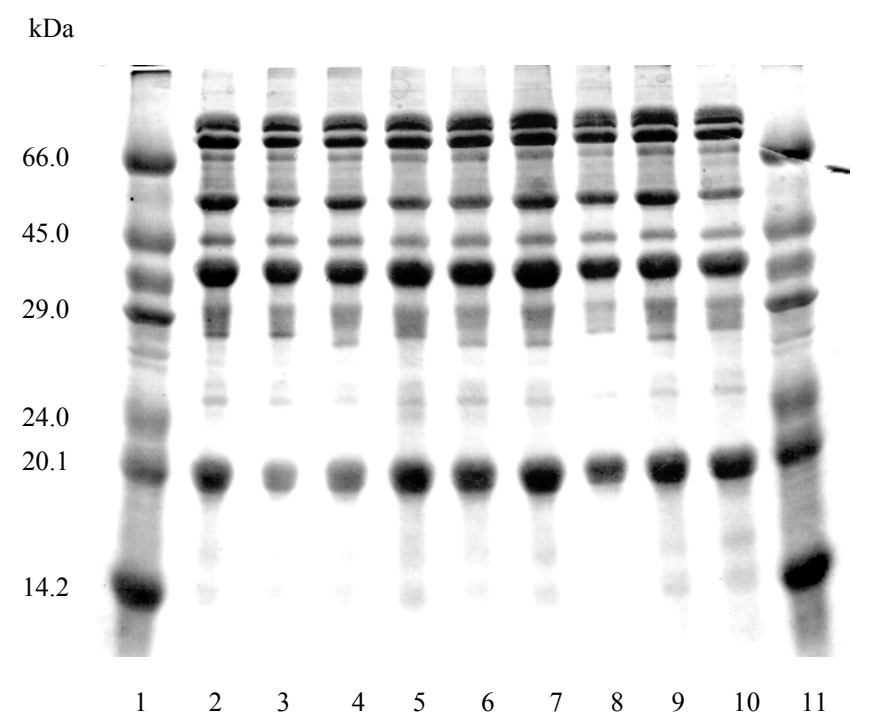

Figure 1. Polyacrylamide gel electrophoresis of nine Brazilian soybean cultivars adapted to low latitude regions. Lanes 1 and 11: molecular mass standards are shown $(\mathrm{kDa})$ on the left; lane 2. G. max 'M. Soy 108'; lane 3. G. max 'Pati'; lane 4. G. max 'Mirador', lane 5. G. max 'Seridó-RCH'; lane 6. G. max 'FT 106'; lane 7. G. max 'FT 107'; lane 8. G. max 'Cristalina-RCH', lane 9. G. max '9001' and lane 10. G. max 'Sambaíba'. Molecular mass markers were bovine serum albumin (66.0 kDa), egg white albumin $(45.0 \mathrm{kDa})$, glyceraldehyde-3-phosphate dehydrogenase $(36.0 \mathrm{kDa})$, carbonic anhydrase $(29.0 \mathrm{kDa})$, trypsinogen $(24 \mathrm{kDa})$, soybean trypsin inhibitor $(20.1 \mathrm{kDa})$ and a-lactalbumin $(14.2 \mathrm{kDa})$. 
feed as well as studies on the resistance of this crop to disease and pests.

Acknowledgements - This work was supported by "Conselho Nacional de Desenvolvimento Científico e Tecnológico" (CNPq/PADCT), "Coordenação de Aperfeiçoamento de Pessoal de Nível Superior" (Capes/ Procad), and "Fundação de Amparo à Pesquisa do Estado do Ceará" (Funcap). The authors are grateful to Dr. Gisela Introvini (Fapcen) for providing the soybean cultivars.

\section{References}

ALMEIDA, L.A., KIIHL, R.A.S., MIRANDA, M.A.C. \& CAMPELO, G.J.A. 1999. Melhoramento da soja para regiões de baixas latitudes, In Recursos genéticos e melhoramento de plantas para o nordeste brasileiro (M.A. Queiroz, C.O. Goedert \& S.R.R. Ramos, eds.). http://www.cpatsa.embrapa.br .

AOAC, 1990. Association of Analytical Chemists. Official methods of analysis, Washington D.C.

ARMOUR, J.C., PERERA, R.L.C., BUCHAM, W.C. \& GRANT, G. 1998. Protease inhibitors and lectins in soya bans and effects of aqueous heat-treatment. Journal of the Science of Food and Agriculture 78:225-231.

BAETHGEN, W.E. \& ALLEY, M.M. 1989. A manual colorimetric procedure for measuring ammonium nitrogen in soil and plant Kjeldahl digests. Communications in Soil Science and Plant Analysis 20:961-969.

BAJPAI, S., SHARMA, A., GUPTA, M.N. 2005. Removal and recovery of antinutritional factors from soybean flour. Food Chemistry 89:497-501.

BAU, H., VILLAUME, C., NICOLAS, J. \& MÉJEAN, L. 1997. Effect of germination on chemical composition, biochemical constituents and antinutritional factors of soya bean (Glycine max) seeds. Journal of the Science of Food and Agriculture 73:1-9.

BRADFORD, M.M. 1976. A rapid and sensitive method for the quantitation of micrograms quantities for proteins utilizing the principle of protein-dye binding. Analytical Biochemistry 72:248-254.

BRASIL, I.C.F. 2002. Avaliação bioquímica e nutricional da soja comercial submetida a diferentes processamentos. Tese de doutorado, Universidade Federal do Ceará, Fortaleza.

CAMPELO, G.J.A., KIIHL, R.A.S. \& ALMEIDA, L.A. 1999. Características agronômicas e morfológicas das cultivares de soja desenvolvidas para as regiões de baixas latitudes, In Recursos genéticos e melhoramento de plantas para o nordeste brasileiro (M.A. Queiroz, C.O. Goedert \& S.R.R. Ramos, eds.). http:// www.cpatsa.embrapa.br.
CLARKE, E.J. \& WISEMAN, J. 2000. Developments in plant breeding for improved nutrition quality of soya beans II. Antinutritional factors. Journal of Agricultural Science 134:125-136.

DURANTI, M. \& GIUS, C. 1997. Legume seeds: protein content and nutritional value. Field Crops Research 53:31-45.

EVENEPOEL, P., HIELE, M., GEYPENS, B., GEBOES, K.P., RUTGEERTS, P. \& GHOOS, Y. 2000. C-13-egg white breath test: a non-invasive test of pancreatic trypsin activity in the small intestine. Gut 46:52-57.

FAO/WHO/UNU, 1985. Energy and protein requirements. FAO/WHO/UNU Technical Report Series No 724, Geneva.

FÉRNANDEZ-QUINTELA, A., MACARULLA, M.T., DEL BARRIO, A.S. \& MARTINEZ, J.A. 1997. Composition and functional properties of protein isolates obtained from commercial legumes grown in northern Spain. Plant Foods for Human Nutrition 51:331-342.

FERNÁNDEZ-QUINTELA, A., BARRIO, A.S., MACARULLA, M.T. \& MARTÍNEZ, J.A. 1998. Nutritional evaluation and metabolic effects in rats of protein isolates obtained from seeds of three legume species. Journal of the Science of Food and Agriculture 78:251-260.

FOLLMER, C., BARCELLOS, G.B.S., ZINGALI, R.B., MACHADO, O.L.T., ALVES, E.W., BARJA-FIDALGO, T.C., GUIMARÃES, J.A. \& CARLINI, C.R. 2002. Canatoxin, a toxic protein of jack beans (Canavalia ensiformis), is a variant form of urease (EC 3.5.1.5). Biological effects of urease independent of its ureolytic activity. Biochemical Journal 360:217-224.

FRIEDMAN, M. \& BRANDON, D.L. 2001. Nutritional and health benefits of soy proteins. Journal of Agricultural and Food Chemistry 49:1069-1086.

FRIEDMAN, M., BRANDON, D.L., BATES, A.H. \& HYMOWITZ, T. 1991. Comparison of a commercial soyabean cultivar and an isoline lacking the Kunitz trypsin inhibitor: composition, nutritional value and effects of heating. Journal of Agricultural and Food Chemistry 39:327-335.

GEHRKE, C.W., WALL, L.L.,ABSHEER, J.S., KAISER, F.E. \& ZUMWALT, R.W. 1985. Sample preparation for chromatography of amino acids: acid hydrolysis of proteins. Journal of Association of Official Analytical Chemistry 68:811-821.

HAMERSTRAND, G.H., BLACK, L.T. \& GLOVER, J.D. 1981. Trypsin inhibitors in soy products: modification of the standard analytical procedure. Cereal Chemistry 58:42-45.

KAKADE, M. L., RACKIS, J.J, MCGHEE, J. E, PUSKI, G. 1974. Determination of trypsin-inhibitor activity of soy products - collaborative analysis of an improved procedure. Cereal Chemistry 51:376-382.

KAPLAN, A. 1969. The determination of urea, ammonia and urease, In Methods of Biochemical Analysis (D. Glick, ed.). John Wiley \& Sons, New York, p.311-324. 
LAEMMLI, U.K. 1970. Cleavage of structural proteins during the assembly of the head of the bacteriophage $\mathrm{T}_{4}$. Nature 227:679-685.

LAJOLO, F.M. \& GENOVESE, M.I. 2002. Nutritional significance of lectins and enzyme inhibitors from legumes. Journal of Agricultural and Food Chemistry 50:6592-6598.

MESSINA, M.J. 1999. Legumes and soybeans: overview of their nutritional profiles and health effects. American Journal of Clinical Nutrition 70:439-450.

MOREIRA, R.A. \& PERRONE, J.C. 1977. Purification and partial characterization of a lectin from Phaseolus vulgaris. Plant Physiology 59:783-787.

NIELSEN, N.C. 1985. Structure of soy proteins, In New Protein Foods 5: seed storage proteins (A.M. Altshul \& H.L. Wilcke, eds.). Academic Press, Orlando, p. 27-64.

OLGUIN, M.C., HISANO, N., D’OTTAVIO, A.E., ZINGALE, M.I., REVELANT, G.C. \& CALDERARI, S.A. 2003. Nutritional and antinutritional aspects of an Argentinian soybean flour assessed on weanling rats. Journal of Food Composition and Analysis 16:441-449.

PINTÉR-SZAKÁCS, M. \& MOLNÁR-PERL, H. 1990. Determination of tryptophan in unhydrolyzed food and feedstuffs by the acid ninhydrin method. Journal of Agricultural and Food Chemistry 38:720-726.

POLACCO, J.C. \& HOLLAND, M.A. 1993. Roles of urease in plant cells. International Reviews of Citology 145:65-103.

PUSZTAI, A., GRANT, G., BROWN, D.S., EWENS, S.W.B., BAINTNER, K., PEUMMANS, W.J. \& VAN DAMME, E.J.M. 1995. Lectins binding to the gut wall are growth factors for the pancreas: nutritional implications for transgenic plants. In Lectins - Biomedical Perspectives (A. Pusztai \& S. Bardocz, eds.). Taylor \& Francis, London, p.141-154.

QIN, G.X., VERSTEGEN, M.W.A. \& VAN DER POEL, A.F.B. 1998. Effect of temperature and time during steam treatment on the protein quality of full-fat soybeans from different origins. Journal of the Science of Food and Agriculture 77:393-398.

RIDLEY, W.P., SHILLITO, R.D., COATS, I., STEINER, H.Y., SHAWGO, M., PHILliPS, A., DUSSOLD, P. \& KURTYKA, L. 2004. Development of the International Life Sciences Institute crop composition database. Journal of Food Composition and Analysis 17: 423-438.

SOUSA, D.O.B. 2001. Avaliação bioquímica e nutricional da soja [Glycine $\max (\mathrm{L})$ Merr.] cv. Seridó e Seridó-RCH. Tese de doutorado, Universidade Federal do Ceará, Fortaleza, Ceará.
THANH, V.H. \& SHIBASAKI, K. 1977. Beta-conglycinin from soybean proteins. Isolation and immunological and physicochemical properties of the monomeric forms. Biochimica and Biophysica Acta 490:370-384.

VAN BARNEVELD, R.J. 1999. Chemical and physical characteristics of grains related to variability in energy and amino acid availability in pigs: a review. Australian Journal of Agricultural Research 50:667-687.

VASCONCELOS, I.M., CAVADA, B.S., MOREIRA, R.A. \& OLIVEIRA, J.T.A. 1991. Purification and partial characterization of a lectin from seeds of Dioclea guianensis. Journal of Food Biochemistry 15:137-154.

VASCONCELOS, I.M., TRENTIN, A., GUIMARÃES, J.A. \& CARLINI, C.R. 1994. Purification and physicochemical characterization of soyatoxin, a novel toxic protein isolated from soybeans (Glycine max). Archives of Biochemistry and Biophysics 312: 357-366.

VASCONCELOS, I.M., SIEBRA, E.A., MAIA, A.A.B., MOREIRA, R.A., NETO, A.F., CAMPELO, G.J.A. \& OLIVEIRA J.T.A. 1997. Composition, toxic and antinutritional factors of newly developed cultivars of Brazilian soybean (Glycine max). Journal of the Science of Food and Agriculture 75:419-426.

VASCONCELOS, I.M., MAIA, A.A.B., SIEBRA, E.A., OLIVEIRA, J.T.A., CARVALHO, A.F.F.U., MELO, V.M.M., CARLINI, C.R. \& CASTELAR, L.I.M. 2001. Nutritional study of two Brazilian soybean (Glycine max) cultivars differing in the contents of antinutritional and toxic proteins. Journal of Nutritional Biochemistry 12:1-8.

VIEIRA, C.R., CABRAL, L.C. \& PAULA, A.C.O. 1999. Proximate composition and amino acid, fatty acid and mineral contents of six soybean cultivars for human consumption. Pesquisa Agropecuária Brasileira 34:1277-1283.

VOLLMANN, J., FRITZ, C.N., WAGENTRISTL, H. \& RUCKENBAUER, P. 2000. Environment and genetic variation of soybean seed protein content under Central European growing conditions. Journal of the Science of Food and Agriculture 80:1300-1306.

WILCOX, J.R. 1998. Increasing seed protein in soybean with eight cycles of recurrent selection. Crop Science 38:1536-1540.

ZELLER, F.J. 1999. Soybean (Glycine max (L.) Merr.): utilization, genetics, biotechnology. Bodenkultur 50:191-202. 